\title{
Eğitim Enstitülerinde Yönetim
}

\section{Administration in Education Institutes}

\author{
Doç. Dr. Fatih DEMIREL ${ }^{1}$, Rukiye KÖSE ${ }^{2}$
}

\begin{abstract}
$\ddot{\mathbf{O} z}$
Türkiye'de bir meslek olarak öğretmen yetiştirme Osmanlı Devleti’nin modernleşme sürecinde açılan okullarla başlamıştır. Osmanlı Devleti'nden alınan miras Türkiye Cumhuriyeti'nde devam ettirilmiştir. Bunun yanında öğretmen yetiştiren yeni kurumlar da açılmıştır. Cumhuriyet Dönemi’nde, ortaokullara öğretmen yetiştirmek için ilk olarak Gazi Eğitim Enstitüsü açılmıştır. 1940’tan sonra, aynı amaçla, eğitim enstitülerinin sayısı artmaya başlamıştır. Bu çalışma, 1946 sonrasında açılmasına karar verilen eğitim enstitülerinin yönetiminin nasıl tasarlandığını ve uygulandığını açıklamayı amaçlamaktadır.
\end{abstract}

Anahtar Kelimeler: Eğitim enstitüsü, öğretmen yetiştirme, okul yönetimi

Makale Türü: Derleme

\begin{abstract}
In Turkey, the profession of teacher training started with the schools that were opened during the modernization period of the Ottoman Empire. This inheritance from the Ottoman Empire was maintained in the Republic of Turkey. In addition, new teacher training institutions were also established. In the Republican Period, the Gazi Education Institute was the first institute established in order to train teachers for secondary schools. After 1940, to serve the same purpose the number of education institutes began to increase. The present study aims to describe how the administration of the education institutes, that were founded after 1946, were designed and implemented.
\end{abstract}

Keywords: Education institute, teacher training, school management

Paper Type: Review

\section{Giriş}

Sultan II. Mahmud, Osmanlı Devleti'nde, sivil alandaki yeni tarz eğitim kurumu olan Mekteb-i Maârif-i Adliyeyi 1839 yılında kurdurmuştur. Adı geçen okul, rüşdiye mekteplerinin ilk örneğini oluşturmaktadır. Tanzimat Dönemi’nde rüşdiye mekteplerinin sayısı çoğaltılmaya başlanmıştır (Demirel, 2002: 47-48). Osmanlı Devleti'nin kuruluşundan beri var olan sıbyan mektepleri ve medreselerden farklı bir yapıda kurulan rüşdiye mekteplerinin çoğalmaya başlamasıyla birlikte, yeni okullarda istihdam edilecek öğretmenlere ihtiyaç duyulmuştur. $\mathrm{Bu}$ doğrultuda, 16 Mart 1848'de Darülmuallimin (-i Rüşdi) açılmıştır (Ünal ve Birbudak, 2013: 10). Tanzimat Dönemi'nde kızlar için de Darülmuallimat ismiyle bir öğretmen okulu açılmıştır (Taşer, 2010; Öztürk, 1998). Tarihi süreçte Darülmualliminin yapısında çeşitli değişiklikler yapılmıştır. 1869 'da yürürlüğe giren Maarif-i Umumiye Nizamnamesi ile kurulmasına karar verilen Büyük Darülmualliminin üç şubesinden biri rüşdiyelere öğretmen yetiştirmek için ayrılmıştır (Maarif-i Umumiye Nizamnamesi, 1286: 19). Sultan II. Abdülhamid Dönemi'nde, 1891'de Darülmualliminin yapısında değişikliğe gidilmekle birlikte Rüşdiye şubesi varlığını korumuştur. II. Meşrutiyet'in ilanından hemen sonra İstanbul Darülmuallimininin yapısında değişikliğe gidilerek İbtidai, Mahreç ve Âlî olmak üzere üç şubeden oluşmasına karar verilmiştir. Bu değişiklikle Rüşdiye şubesinin yerini Mahreç şubesi almıştır (Ünal ve Birbudak,

\footnotetext{
${ }^{1}$ Bursa Uludağ Üniversitesi, Eğitim Fakültesi, fatihdemirel@uludag.edu.tr, Orcid ID: https://orcid.org/0000-0002-2098-4786.

${ }^{2}$ Bursa Uludağ Üniversitesi, Eğitim Bilimleri Enstitüsü, rukiye.kose.95@hotmail.com, Orcid ID: https://orcid.org/ 0000-0003-2407$121 X$.

Atıf için (to cite): Demirel, F. ve Köse, R. (2019). Eğitim Enstitülerinde Yönetim. Afyon Kocatepe Üniversitesi Sosyal Bilimler Dergisi, 21(2), 515-528.
} 
2013: 37-48). 1913 y1lında yürürlüğe giren, Tedrisat-ı İbtidaiye Kanun-ı Muvakkati ile ibtidai ve rüşdiye mektepleri birleştirilmek suretiyle 6 yıl süreli yeni bir yapılanmaya gidilmiştir. 6 yıllık sürenin son iki yılı eski rüşdiye mekteplerine denk sayılmıştır (Demirel, 2012: 525). Okul kademelerindeki bu yapısal değişikliğin etkisiyle, 1915 yılında yapılan düzenlemede Darülmuallimin-i Âliye, İbtidai, İhzari ve Âlî olmak üzere üç şube şeklinde tasarlanmıştır. İlgili düzenleme ile 2 yıl süreli İhzari şubesinden mezun olacaklara, iptidailere öğretmen ve müfettiş olma hakkı tanınmıştır (Ünal ve Birbudak, 2012: 49). İhzari şubesi, gerekli altyap1 oluşturulmadan açılmış olması ve öğrencilerinin çoğunun, askere alınmış olması nedenleriyle, kısa bir süre sonra kapatılmıştır (İhsaiyat Mecmuası 1339-1340, 1341: 45).

Böylece, II. Meşrutiyet Dönemi'nde Mahreç ismini almış olan Darülmualliminin Rüşdiye şubesi, yukarıda zikredilen, 1913 yılındaki yeni yapı doğrultusunda kapatılmıştır (Ünal ve Birbudak, 2013: 49). Tanzimat Dönemi ve sonrasında, yukarıda kısaca ifade edilen, İstanbul'da açılmış olan öğretmen okullarından başka, vilayetlerde de ibtidai mekteplerine öğretmen yetiştirmek için darülmualliminler açılmıştır.

Osmanlı Devleti'nde açılmış olan öğretmen okullarının birçoğu Cumhuriyet Dönemi'nde varlığını devam ettirmiştir. 1923 yılında İstanbul dışında, 12 vilayette darülmuallimin, 6 vilayette darülmuallimat bulunmaktadır (İhsaiyat Mecmuas1 1339-1340, 1341: 44). $1923^{3}$ y1lında ibtidai darülmualliminlere muallim ve ibtidai mektepleri için müfettiş yetiştirmek amaciyla İstanbul Darülmuallimini bünyesinde “Orta Darülmuallimin” adıyla bir şube açılmıştır (İhsaiyat Mecmuası 1339-1340: 45). 1924 yılının ilk aylarında Orta Darülmuallimin ve Darülmuallimat idareci ve öğretmenlerinden oluşan bir komisyon, okulun amaçlarından birinin de ortaokullara (lise birinci devre) öğretmen yetiştirmek olduğunu ifade etmiştir (Şevket, 1924: 575-577). Cumhuriyet Dönemi'nde ortaokullara öğretmen yetiştirmek için açılmış olan bu şubenin ömrü fazla olmamıştır. 1924'te Darülmuallimin-i Âlînin Âlî şubesi "Yüksek Muallim Mektebi" ismiyle Darülfünuna bağlanmıştır (Becerikli, 2019). Zikredilen bu değişiklikle birlikte Orta Darülmualliminin öğrencileri Yüksek Muallim Mektebine devredilmiştir (İhsaiyat Mecmuası 1339-1340, 1341: 45). Böylece Orta Darülmuallimin kapanmıştır.

Gazi Eğitim Enstitüsü, Orta Muallim Mektebi adıyla 1926-1927 öğretim yılında açılmış ve böylece Cumhuriyet Dönemi'nde ortaokullara öğretmen yetiştirme yönünde önemli bir adım atılmıştır (Duman, 1991: 47). 1944 yılında Balıkesir Öğretmen Okulunda, yüksek kısım olarak ifade edilen Necati Eğitim (Terbiye) Enstitüsü ve Orta Öğretmen Okulu açılmıştır. Başlangıçta yalnızca iki şubeyle (Matematik, Fizik-Kimya) öğretime başlanmıştır (Ayas, 1948: 348; Necati Eğitim Enstitüsü, 1948: 32). Böylece, Cumhuriyet Dönemi'nde ortaokullara öğretmen yetiştiren ikinci kurum teşkil edilmiştir. 1950 sonrasında ortaokullara öğretmen yetiştiren okulların sayısı artmaya başlamış ve onlar üç yıllık eğitim enstitüleri olarak adlandırılmışlardır. 1978-1979 öğretim yılından itibaren yüksek öğretmen okulu olarak adlandırılan bu müesseselerin öğretim süresi 4 yıla çıkarılmıştır. Yüksek öğretmen okulları 1982'de eğitim fakültelerine dönüştürülmüşlerdir (Akyüz, 2012: 387).

Yukarıda kısaca tarihi süreçteki gelişimi ele alınan Eğitim Enstitülerini farklı yönleriyle inceleyen birçok çalışma bulunmaktadır. Bunlardan en kapsamlısı Niyazi Altunya (2006) tarafından kaleme alınan, Gazi Ĕgitim Enstitüsü, Gazi Orta Öğretmen Okulu ve Eğitim Enstitüsü (1926-1980) adlı eserdi. Eserde, Gazi Eğitim Enstitüsü temel alınmak suretiyle genel olarak eğitim enstitüleri çeşitli yönleriyle incelenmiştir. Tayyip Duman'ın hazırlamış olduğu Türkiye'de Ortaöğretime Öğretmen Yetiştirme (Tarihi Gelişimi), Cemil Öztürk tarafından yazılmış Türkiye’de Dünden Bugüne Öğretmen Yetiştiren Kurumlar, eğitim enstitülerini de ele alan eserlerdir (Duman, 1991; Öztürk, 1998). Yine Mustafa Yılman tarafindan hazırlanmış,

\footnotetext{
3 İhsaiyat Mecmuasında şubenin açılış tarihi 1924 (R. 1340) olarak verilmiştir. Sabri Becerikli şubenin açılış tarihini 1923 olarak vermiş̦tir. Becerikli'nin kullanmış olduğu belge (Cumhuriyet Arşivi: 180.09.0.0/78.382.1.) ve Süleyman Şevket'in Muallimler Mecmuasında yayınlanmış makalesi dikkate alındığında şubenin 1923 yılında açılmış olduğu anlaşılmaktadır. (İhsaiyat Mecmuası 1339-1340, 1341: 45; Becerikli, 2019: 154; Şevket, 1924: 575).
} 
Türkiye'de Ortaögrretime Öğretmen Yetiştirme Sisteminin Pedagojik Temelleri başl1klı bir doktora tezi bulunmaktadır (Yılman, 1987). Eğitim enstitülerini çeşitli yönleriyle ele alan makaleler de mevcuttur (Erdem, 2015; Kavcar, 2002; Mustafa Güçlü, 2013; Becerikli ve Demirel, 2017). Eğitim enstitüleri ile ilgili çalışmalarda, onların yönetiminin nasıl tasarlanmış olduğu ve tarihi süreçte nasıl bir değişim yaşandığı açık bir şekilde ortaya konulmamıştır. Çalışmaların çoğunda yönetimle ilgili oldukça kısıtlı bir değerlendirme yapılmıştır.

Bu çalışmanın amacı 1946 sonrasında eğitim enstitülerinin açılma kararının alınmasını müteakip hazırlanan yönetmeliklerde okulların yönetiminin nasıl tasarlandığını ortaya çıkarabilmektir. Diğer taraftan yönetmeliklerle alınan kararların eğitim enstitülerinde nasıl uygulandığı değerlendirilmeye çalış1lacaktır.

\section{Eğitim Enstitüsü Yönetmelikleri}

Yukarıda ifade edildiği üzere Cumhuriyet Dönemi'nde ortaokullara öğretmen yetiştirmek amacı doğrultusundaki ilk ciddi girişim Gazi Eğitim Enstitüsüdür. 29 Kasım 1926'da yürürlüğe giren, Orta Muallim Mektebi Muvakkat Talimatnamesi bu okulun işleyişini tasarlamıştır. On üç maddeden oluşan talimatname genel olarak öğrenci kabul şartlarını ve sürecini ele almaktadır. Diğer birçok konuda ayrıntıya girilmemiş ve okulun dâhili idaresinde, ilk muallim mekteplerinde uygulanan usullere uyulacağı ifade edilmiştir (Orta Muallim Mektebi Muvakkat Talimatnamesi, 1927: 14-16).

1931 yılında Gazi Muallim Mektebi: Teşkilat ve Programlar adıyla hazırlanan el kitabında okulun yönetimiyle ilgili düzenlemelerin de yapıldığı anlaşılmaktadır. 1932 yılında Gazi Terbiye Enstitüsü Talimatnamesi hazırlanmıştır. 44 maddeden oluşan bu talimatnamenin ilk maddesinde Gazi Terbiye Enstitüsünün amacı belirtilmektedir. Buna göre Enstitünün amac1, "ortamekteplere ve orta derecedeki meslek mekteplerine muallim, ilkmekteplere müdür ve müfettiş, umumiyetle beden terbiyesi, resim-iş dersi muallimi yetiştirmek ve ihtiyaca göre açılacak kurslar vasıtasıyla mevcut muallimlerin ihtisaslarını artırmak" şeklinde ifade edilmiştir. Talimatnamenin diğer maddeleriyle okulun teşkilatı, şubeleri ve yönetimi de belirlenmiştir (Altunya, 2006: 106-115).

1946'da eğitim enstitülerinin açılma kararının alınmasından sonra 1947'de, onlar için geçici bir yönetmelik hazırlanmıştır. Eğitim Enstitüleri Geçici Yönetmeliği 96 maddeden oluşmaktadır. $\mathrm{Bu}$ maddelerden 2'si geçici maddelerdir. Bu yönetmeliğin ilk iki maddesinde enstitülerinin amaçlarına yer verilmiştir. Buna göre, eğitim enstitüsü, ilk ve ortaokulu içine alan, öğrenim süresi sekiz yıllık okullara, orta dereceli öğrenim kurumlarına ve köy enstitülerine öğretmen yetiştiren bir yükseköğrenim kurumudur. Yönetmelik'te eğitim enstitüsünün amacının; milli ahlak ilkelerine bağlı, millet ve insanlık ülküsünü benimsemiş, pozitif bilim anlayışını kazanmış ve bilgilerini meslek alanında kullanma yollarını hakkıyla öğrenmiş, çalışkan, mesleğine bağlı, vatanın her yerinde seve seve hizmette bulunmaya hazır, yaşayışı ve çevresine yaptığı etki bakımından örnek tutulmaya layık, bedence ve karakterce sağlam, şahsiyet sahibi öğretmenler yetiştirilmesi olduğu ifade edilmektedir (Eğitim Enstitüleri Geçici Yönetmeliği, 1947: 173). 1952'de Öğretmen Yetiştiren Okul ve Enstitülere Öğrenci Kayıt ve Kabul İşleri Hakkında Genelge ve Geçici Yönetmelik başlığıyla yeniden bir geçici yönetmelik çıkarılmış (Altunya, 2006: 1345).

Yukarıda ifade edilen iki geçici yönetmelikten sonra 29 Eylül 1955'te eğitim enstitülerinin ilk yönetmeliği olan Eğitim Enstitüsü Yönetmeliği çıkarılmıştır. 70 maddeden oluşan bu yönetmeliğin 4 de geçici maddesi bulunmaktadır. 1955 yılında çıkarılan Eğitim Enstitüsü Yönetmeliği'nin ilk maddesi eğitim enstitülerinin amaçlarını belirlemiştir. Buna göre, "Ë̆itim Enstitüsü, ortaokullarla muadili ögretmen öğretim kurumlarına ve ilk öğretmen okullarına öğretmen, ilköğretime müfettiş ve ilk ögretmen okullarına bağll uygulama okullarına başögretmen yetiştiren; ilk ve ortaokullarda ve ilk ögretmen okullariyla ilgili problemler üzerinde incelemeler yapan ve bu okullar ögretmenlerinin mesleki gelişimlerine yardım eden bir yüksekögrenim kurumudur “. Maddenin devamında, Eğitim Enstitüleri Geçici Yönetmeliği’nde 
(1947) ifade edilmiş olan, yetiştirilecek öğrencilerden beklenenler sıralanmıştır (Eğitim Enstitüsü Yönetmeliği, 1955: 3-5).

Eğitim Enstitüleri ile ilgili bir sonraki yönetmelik 25 Kasım 1968 tarihinde çıkarılmışırı (Eğitim Enstitüsü Yönetmeliği, 1968: 495-496). 3'ü geçici olmak üzere 83 maddeden oluşan bu yönetmelikten kısa bir süre sonra, 16 Mayıs 1969'da yeniden bir Eğitim Enstitüsü Yönetmeliği yayınlanmıştır. $\mathrm{Bu}$ yönetmeliğin 81 maddesi ve 2 geçici maddesi bulunmaktadır (Eğitim Enstitüsü Yönetmeliği, 1969: 4-5). Enstitülerin yap1 ve amaçları bakımından bir önceki yönetmelikle aralarında önemli bir fark bulunmamaktadır.

\section{Eğitim Enstitülerinde Yönetim}

Enstitülerin yönetim organlarını müdürlük, enstitü kurulu, genel öğretmenler kurulu, bölüm öğretmenler kurulu, yönetici kurulu ve disiplin kurulu oluşturmaktaydı (Altunya, 2006: 115). Bu yapı ana hatlarıyla enstitülerin fakülteye dönüşümüne kadar devam etmiştir.

\subsection{Enstitü Müdürü}

Gazi Terbiye Enstitüsü Talimatnamesi’nde (1932) kısa bir şekilde açıklanmış olsa da daha sonra çıkan diğer yönetmeliklerde tanımlandığı şekliyle müdürün, yetki ve görevleri arasında önemli farklar bulunmamaktadır. Müdür, enstitüdeki eğitim-öğretim ve yönetimin sorumlusu, düzenleyicisi ve amiridir. Görevleri şunlardır:

a) Enstitüyü temsil eder. Enstitüye ve öğrenciye ait evrakı onaylayıp, imzalar.

b) Müdür yardımcılarının, bölüm şeflerinin, öğretmenlerin, asistanların ve memurların tayinleri ve terfileri için gerekli yazışmayı yapar.

a) Maarif Vekâletine enstitü bütçesi hakkında teklifte bulunur.

b) Enstitünün kurul ve komisyonlarına başkanlık eder.

c) Her yıl temmuz ayının sonunda enstitünün bütün çalışmalarıyla ilgili Vekâlete rapor verir.

d) Enstitüdeki öğretim ve uygulama çalışmalarını yönetir, düzeni sağlar ve eğer gerekirse derslere girerek çalışmaları denetler (Eğitim Enstitüsü Yönetmeliği, 1955: 9-10).

Müdürler eğitim enstitülerinin kurumsallaşmasında önemli bir rol oynamışlardır. Örneğin İzmir Eğitim Enstitüsünün ilk müdürü 10 yıl süre ile görevinde kalmış ve başarılı bir yönetim sergilemiştir. Aynı enstitüde 1974 yılı sonrasında kısa süreli müdür değişiklikleri olmuş; bu da yönetimde başarısızlıklara neden olmuştur (Şahin, 2002: 38).

Eğitim enstitüsü müdürleri, yöneticiliklerinin yanında, eğitim-öğretimle ilgili çeşitli konularda yazılar kaleme almışlardır. Bursa Eğitim Enstitüsü Müdürü Yusuf Z. Beyzadeoğlu'nun, Enstitü tarafından çıkarılan Alkım dergisinde birçok yazısı mevcuttur. Örneğin: "Mektupla Öğretimin Sonu" başlıklı yazısında, mektupla öğretmen yetiştirme uygulamasının başarısızlıkları üzerinde durmaktadır (Beyzadeoğlu, 1976: 16-18).

\subsection{Enstitü Müdür Başyardımcısı ve Müdür Yardımcıları}

Müdürle birlikte, okulun idari işlerini yürütmek için müdür başyardımcısı ve müdür yardımcıları tanımlanmıştır. Okul müdürü Maarif Vekâletinin iznini almak suretiyle müdür yardımcılarından birini başyardımcı olarak görevlendirir (Eğitim Enstitüsü Yönetmeliği, 1955: $10)$.

Müdür başyardımcısı, müdürün vereceği emirlerle direktifleri uygular. Enstitü büro işlerinin düzenleyicisi ve müdürün iş başında olmadığ 1 zamanlarda onun vekilidir. $\mathrm{Bu}$ madde hükümleri gereğince başyardımcı şu işleri yapar:

a) Enstitünün öğrenci kayıt-kabul ve yazı işlerini düzenler, gerekli cetvellerin gününde hazırlanmasını sağlar. 
b) Öğrencilerin devamlarına, imtihanlara ve diğer işlere ait defter, cetvel, diploma ve dosyaların hazırlanmasını sağlar. Yukarıda ifade edilen belgeleri inceleyerek müdürle beraber imzalar.

c) Okulun disiplin işlerini düzenler ve bu işleri yakından gözleyerek ilgilileri göreve çağırır.

d) Tahakkuk memuru görevini yapar ve bu sıfatla bütün ödeme ve gider tahakkuk evrakını inceleyerek imzalar. Enstitüye alınan eşya ve erzakın satın alınması ve kontrolü için oluşturulan kurullara başkanlık eder.

e) Ambar ve depo ile ilgi işlemleri, en az ayda bir defa kontrol ve teftiş eder.

f) Müdür yardımcıları gibi nöbetle enstitüde kalır.

g) Enstitü disiplin kuruluna başkanlık eder.

h) Öğretmenlerden ve memurlardan görevlerine geç gelenleri veya gelmeyenleri yazı ile müdüre bildirir.

i) Öğrencilere ait izin işlerini müdürden aldığı direktif dâhilinde yürütür (Eğitim Enstitüleri Geçici Yönetmeliği, 1947: 174).

1955 ve sonrasında çıkarılan yönetmeliklerde müdür başyardımcısının görev ve sorumlulukları arasında önemli farklı1ıklar bulunmamaktadır.

1947'de çıkarılan geçici yönetmelikle müdür yardımcılarının görevi, temel olarak, müdür tarafından verilen görev ve emirlerin başyardımcının nezareti altında yürütülmesi olarak tanımlanmıştır. Enstitünün eğitim, yönetim ve yazı işlerinden müdür yardımcılarına verilecek görevler müdür tarafından her birine ders yılı başında bildirilir. Müdür yardımcıları, bundan başka, nöbetle enstitüde kalarak enstitünün işlerine ve öğrencilerine nezaret ederler. Nöbetçilik yirmi dört saat devam eder. Müdür başyardımcısı ve yardımcıları nöbetçi oldukları zamanlarda enstitünün gündelik işlerinin düzenli yürütülmesinden birinci derecede sorumludurlar (Eğitim Enstitüleri Geçici Yönetmeliği, 1947: 174-175).

Eğitim enstitüsü yönetmeliklerinde, müdür yardımcılarının görevleri ana hatlarıyla yukarıda verildiği gibidir. 1955 'te çıkarılan yönetmelikte, hangi işlerin hangi müdür yardımcısı tarafından yerine getirileceğinin, enstitü müdürü tarafından yazı ile tebliğ edilmesi esası getirilmiştir. Okulda nöbetçi olarak kalan müdür yardımcısının takip edeceği işler ayrıca belirlenmiştir. Nöbetçi müdür yardımcısı nöbet süresince, enstitünün günlük işlerinin düzenli yürütülmesinden birinci derecede sorumludur. Takip edilecek işler aşağıda verildiği gibidir.

a) Vakit cetvellerinin uygulanmasını sağlar.

b) Etütlerin düzenli yapılmasını sağlar.

c) Ambarlardan erzak çıkarılırken hazır bulunur.

d) Tabelaya göre çıkarılan erzakın tam olarak kazana konulmasını, yemeklerin zamanında iyi bir şekilde pişirilip hakkına göre dağıtılmasını kontrol eder.

e) Hastaların bakımı ve hastalanan öğrencilerin durumu ile yakından ilgilenir.

f) Yangın tehlikesi olan yerleri ve gece bekçilerinin, görevlerini gerektiği gibi yapıp yapmadıklarını kontrol eder (Eğitim Enstitüsü Yönetmeliği, 1955: 10-11).

\subsection{Enstitü Öğretmenleri}

1947, 1955, 1968 ve 1969 yıllarındaki yönetmeliklerde öğretmenlerin görevleri detaylı şekilde açıklanmıştır. Zikredilen yönetmeliklerde öğretmenlerin görev ve sorumlulukları ile ilgili bazı farklılıklar da bulunmaktadır. 1947 Eğitim Enstitüleri Geçici Yönetmeliği’nde, enstitü öğretmeninin görevi, yönetmelikle belirlenmiş olan amaçlar doğrultusunda öğrencileri yetiştirmek şeklinde tanımlanmıştır. Öğretmenler, ders yılı içerisinde öğrencilerin her türlü durumlarıyla yakından ilgilenerek, her biri hakkındaki kanaatlerini belirlemekle yükümlüdürler. Öğretmenlerin bu husustaki nihai değerlendirmelerinin her yılın mayıs ayı ortasında enstitü kurulunda görüşülmesi ve konuyla ilgili alınan kararların en geç haziran ayı başında yazılı olarak enstitü yönetimine verilmesi gerekmektedir (Eğitim Enstitüleri Geçici Yönetmeliği, 1947: 175). 1955 ve 1968 yıllarında çıkarılan yönetmeliklerde, seminer, atölye uygulamaları ve 
ders dışı faaliyetlerde de bulanarak hem öğrenci hem de asistan yetiştirmek, öğretmenlerin görevleri arasına eklenmiştir (Eğitim Enstitüsü Yönetmeliği, 1955: 15-16).

1955 yılı ve sonrasında çıkarılan yönetmeliklere göre, öğretmenlerin, öğrencilerin başarıları ve durumları hakkında her dönem başında, bölüm şefi veya müdür ile birlikte rapor hazırlamaları gerekmektedir. Bu raporun bir kopyası enstitüde saklanacak; diğer bir kopyası ise yaz dönemindeki sinavlar bittikten sonra, en geç 1 ay içerisinde Maarif Vekâletine gönderilecektir. Eğer gerekli görülürse, öğretmenlerin ve idarecilerin çalışmaları ve başarı durumları müfettişler tarafından izlenecektir. Enstitü öğretmenleri için yaz döneminde sınavların bitişinden giriş sınavlarının başlayacağı tarihe kadarki süre uzun tatil zamanı olarak belirlenmiştir. Sömestr tatili ise şubat ayında 3 haftadır. Öğretmenler, yukarıda belirtilen tatil zamanlarında, adreslerini okul idaresine bildirmek suretiyle ve toplantı, sinav veya enstitüye ait bir görev olduğunda gelmek şartıyla şehir dışına çıkabileceklerdir. Ancak idari görevi bulunan öğretmenler, izin almadan tatil zamanında görevlerini bırakamazlar. Öğretmenler, tatil zamanları dışında, geçerli bir mazeretleri olmadıkça, enstitünün bulunduğu şehirden ayrılamayacaklardır. Hastalık dışında öğretmenlere yılda toplamda en fazla 3 defa izin verilebilecektir. Bir defada verilen izin 8 günden fazla olmayacaktır. İzin almak isteyen öğretmen öncelikle okul müdürüne müracaat edecektir. Enstitü müdürünün, izin talebini Maarif Vekâletine göndermesi gerekmektedir. Ancak okul müdürüne, acil durumlarda, önemli mazeretlerde, yine bu sürelerde olmak şartıyla izin verme yetkisi tanınmıştır (Eğitim Enstitüsü Yönetmeliği, 1955: 16).

Öğretmenler, maaşlarının karşıllğı olarak haftada 12 saate kadar ders vermekle yükümlü tutulmuşlardır. Öğretmenlere, müdürün izniyle, enstitü dışında, haftada 4 saate kadar ek görev alabilmeleri imkânı da tanınmıştır. Ancak şube ve grup başlarının böyle bir görev alamayacağı belirtilmiştir (Eğitim Enstitüleri Geçici Yönetmeliği, 1947: 175). 1955 ve 1968 yıllarında öğretmenlerin maaş karşıllğı ders yükleri yine haftada 12 saattir. Ancak 12 saatin üzerine ek ders almak isteyen öğretmenler için Maarif Vekâletinin izniyle, haftada 8 saate kadar görev alabilme imkânı tanınmıştır (Eğitim Enstitüsü Yönetmeliği, 1955: 16; Eğitim Enstitüsü Yönetmeliği, 1968: 198).

1969 yılında çıkarılan yönetmeliğe göre öğretmenlerin ders yükü yine 12 saate kadardır. Üzerinde müdür veya müdür yardımcılığı bulananlar ise haftada 4 saat ders vermek ve ayrıca seminer, laboratuvar, atölye çalışmalarını idare etmekle yükümlü tutulmuşlardır. Enstitü öğretmenleri kanunlara uygun olmak şartıyla, haftada $12+6=18$ saate ilaveten, isteğe bağlı olarak 6 saate kadar kendi okullarında ders alabilirler. Diğer okullarda 18 saatin üzerine 6 saate kadar daha ders almalarına Milli Eğitim Bakanlığınca izin verilebilir. Üzerinde idari görev bulunan öğretmenlerin ayrıca bir ek görev almalarına müsaade edilmez (Eğitim Enstitüsü Yönetmeliği, 1969: 7).

İzin almadan veya herhangi bir mazereti olmadan görevini yapmayan, toplantıya katılmayan veya geç kalan öğretmenlere maaş kesme cezası öngörülmüştür. Geç kalan öğretmenler önce idare tarafindan uyarılacak; buna rağmen yine geç kalan öğretmen olursa derse gelmemiş sayılarak gerekli maaş kesim hükümleri uygulanacaktı (Eğitim Enstitüleri Geçici Yönetmeliği, 1947: 175). 1955 ve sonraki yıllarda çıkarılan yönetmeliklerde öğretmenler için maaş kesme cezasına yer verilmemiştir. İlgili yönetmeliklere göre toplantıya, sınavlara veya göreve bir kez gelmeyen öğretmenler 1 gün devamsız sayılacaktır. Öğretmenlerin disiplin işleriyle müdürün teklifi doğrultusunda Maarif Vekâleti ilgilenecektir (Eğitim Enstitüsü Yönetmeliği, 1955: 16).

Eğitim enstitüsü öğretmenleri, yukarıda belirtilen eğitim-öğretim ve idari faaliyetlerinin yanında çeşitli yayınlar da yapmışlardır. İzmir Eğitim Enstitüsü öğretmenlerinin çalışmalarının bir kısmı kitap olarak yayınlanmıştır. Öğretmenler tarafından hazırlanmış eserlerin bazıları İzmir Eğitim Enstitüsü Öğrenci Derneği tarafından kurulmuş olan Uyanış Dergisi Yayınları arasından çıkmıştır. Tarih, biyoloji, coğrafya, edebiyat, öğretim metotları gibi pek çok alanda 
yayın yapılmıştır (Şahin, 2002: 3638). Yine Bursa Eğitim Enstitüsü öğretmenleri, alanları ile ilgili çeşitli yazılar kaleme almışlardır. Enstitünün dergisi olan Alkım'ın çeşitli sayılarında, öğretmenler tarafından kaleme alınmış pek çok yazı yayınlanmıştır (Alkım, 1974-1976) . Benzer şekilde, Necati Bey Eğitim Enstitüsü tarafından çıkarılan Öğretmence adlı dergide Enstitü öğretmenleri tarafından kaleme alınan yazılar, çeviriler yayınlanmıştır. Örneğin Enstitünün meslek dersi öğretmeni İbrahim Özgür tarafindan çevrilen, idarecilerin görev ve sorumluluklarına dair bir çeviri Öğretmence'de yayınlanmıştır (Zeran ve Jones, 1958: 4-8).

Enstitü öğretmenleri, gerek yurtiçinde ve gerekse yurtdışında çeşitli kurslara katılmışlardır. $\mathrm{Bu}$ uygulamalar enstitü öğretmenleri niteliklerinin gelişiminde ve enstitü başarısında önemli bir etkiye sahip olmuştur. Bursa Eğitim Enstitüsü öğretmenlerinin bazıları çeşitli kurslara katılmışlardır. Öğretmenlerden Fransa, Almanya ve Norveç'e gönderilenler olmuştur (Demirel ve Becerikli, 2017: 359).

\subsection{Enstitü Asistanları}

1955 yılında çıkarılan yönetmelikte enstitülerde asistanlık kadrosu tanımlanmıştır. Asistanlığın amacı eğitim enstitülerine öğretmen yetiştirmektir. Yönetmeliğe göre, eğitim enstitüsü asistanlığına tayin edileceklerin üniversite, yüksek dereceli öğretmen veya ihtisas okulu mezunu olmaları, orta dereceli okullarda başarı ile en az iki yıl öğretmenlik yapmış ve 35 yaşını geçmemiş olmaları şarttır. Pedagoji bölümü asistanlığına alınacakların ise mesleki tecrübe için en az iki yıl başarı ile meslek dersi öğretmenliği veya ilköğretim müfettişliği yapmış olmaları istenmektedir. Asistanların enstitü kadrosuna alımlarında aşağıda verilen yol takip edilmektedir.

a) Asistan alınmasına ihtiyaç olduğu, ilgili bölüm şefi veya temsilcisinin (asistan belli bir bölüm için alınmayacaksa ilgili öğretmenin) teklifi ve enstitü kurulunun kararıla ilan edilerek isteklilere duyurulur.

b) Asistanlığa tayin olmak isteyenler dilekçe ile enstitü müdürlüğüne müracaat ederler. Bunların durumları ilgili bölüm öğretmenler kurulunda (o enstitüde söz konusu ihtisas bölümü yoksa başka bir enstitüdeki ilgili ögretmenler kurulunda) incelenir. Şartı haiz görülenler enstitü kurulunca en az üç öğretmenden teşkil olunacak komisyon önünde imtihan edilirler.

c) Asistanlığa girmeye hak kazananlar, enstitü müdürlüğü tarafindan Maarif Vekâletine bildirilir. Vekâlete gönderilen yazıya, ilgili kurul ve komisyonca aday hakkında verilmiş olan karar da eklenir.

Asistanın hangi öğretmenle birlikte çalıştırılacağına, bölüm öğretmenler kurulunun mütalaasını alarak, enstitü kurulu karar verir. Bölümlerin ve derslerin hususiyeti göz önünde tutularak asistanların birden fazla öğretmenle birlikte çalışması kararlaştırılabilir. Bu durumda asistanın üç yıllık çalışma programını ilgili öğretmenler beraber hazırlarlar.

Çalışma programı, asistanın Türkçe, matematik, tabiiye gibi bir ders grubu veya müstakil iki ders öğretmenliğini yapmaya yetki kazanmasını sağlayacak şekilde hazırlanır. Beden eğitimi, resim-iş, müzik bölümü asistanları için bu iki dersten birinin uygulamalı ders olması şarttır. Asistanın, yetiştirileceği alan ile ilgili bulunan başka derslere veya çalışmalara belirli zaman zarfında devam etmesi için de çalışma programına hüküm konulabilir. Çalışma programı enstitü kurulunca tetkik ve tasdik olunur.

Asistanlar günün çalışma saatlerinde enstitüde bulunurlar. Başlıca görevleri şunlardır:

a) Programına göre görevli bulunduğu her çalışmayı yapmak,

b) Yanına verildiği öğretmenlerin enstitüdeki her çeşit öğretim ve eğitim çalışmalarında hazır bulunmak ve bunlara gerektiğinde yardım etmek,

c) Enstitü idaresince, haftada dört saati geçmemek üzere, icabında sorumluluğuna verilecek dersleri ilgili öğretmenin gözetimi ve sorumluluğu altında okutmak, 
d) Öğrencilere ders, deney ve uygulama hazırlıklarında yardım etmek; onların enstitüdeki ders araç ve gereçlerinden faydalanmalarını sağlamak,

e) İlgili öğretmenin kılavuzluğu ile seçeceği bir konuda ve en çok üç yıl içinde bir eser hazırlamak,

f) Esas çalışmalarını aksatmamak şartıyla ve idari sahada yetiştirilmesi amacıyla enstitü müdürlüğünce verilecek nöbet, sınav ve başka eğitim-öğretim faaliyetlerine katılma, kütüphane ve büro çalışmaları gibi işleri yapmak.

Asistanların çalışma ve başarı durumları, her öğretim yılı sonunda, birlikte çalıştıkları öğretmenle bölüm şefi ve enstitü müdürü tarafından ortak düzenlenecek bir raporla tespit edilir. $\mathrm{Bu}$ raporların birer kopyası, enstitü öğretmenleri için düzenlenen raporla birlikte Maarif Vekâletine gönderilir. Bulunduğu aylık derecesindeki kıdem süresini dolduran asistanın aylığı, bu süre içinde başarısı tespit edilmiş olması şartıyla, enstitü müdürlügünün teklifi üzerine Maarif Vekâletince yükseltilir.

Asistanlık görevinde üç yıl başarılı çalışıp yukarıda ifade edilen eseri hazırlayan asistan, enstitü kurulunca seçilecek dört öğretmen ile o asistanı yetiştiren öğretmenlerden oluşan komisyon önünde eserini başarı ile savunur; buna ek olarak komisyonun seçeceği bir konuyu hazırlayıp başarılı bir deneme dersi (teorik ve uygulama olarak) verir. Asistan, yukarıda ifade edilen iki konuda da başarılı olursa enstitü öğretmenliğine tayin edilme ehliyetini kazandığı bir tutanakla tespit olunur. Tutanak, sicil dosyasına konulmak üzere Maarif Vekâletine gönderilir. $\mathrm{Bu}$ gibilerin enstitü öğretmenliğine tayinleri mümkün olmazsa durumlarına uygun bir göreve nakilleri Maarif Vekâletince yapılır. Başarısız olan veya istenilen eseri zamanında hazırlayamayan asistanlar Maarif Vekâletince başka bir göreve nakledilirler (Eğitim Enstitüsü Yönetmeliği, 1955: 18-19).

1955 yılından sonra çıkarılan yönetmeliklerde asistanlıkla ilgili benzer kararlar alınmıştır. Ancak 1968 ve 1969 yıllarında çıkarılan yönetmeliklerde başvuru için aranan şartlar Beden eğitimi ve Müzik bölümleri asistanlıkları için esnetilmiştir. Buna göre ilgili iki alanda orta dereceli okullarda iki yıl öğretmenlik yapmamış olanlar da asistan olarak atanabileceklerdir. $\mathrm{Bu}$ iki alanda hak kazananlar asistanlıkları süresince iki ders y1lı ve haftada 4 saatten az olmamak kaydıyla, orta dereceli bir okulda stajyer öğretmenler gibi derslere devam etmekle ve gereği halinde sorumluluğuna verilecek dersleri okutmakla yükümlü tutulurlar. Asistanın devam edeceği okul, enstitü ve milli eğitim müdürlüklerince birlikte tespit edilir. Bunlar hakkında her ders yılı sonunda staj gördükleri okul müdürlüğünce başarı ve devam durumunu bildirir bir rapor düzenlenerek ilgili eğitim enstitü müdürlüğüne gönderilir. Süresi içinde stajları başarı ile tamamlayamayanlar eğitim enstitüsü öğretmenliğine tayin edilmezler (Eğitim Enstitüsü Yönetmeliği, 1968: 498-499; Eğitim Enstitüsü Yönetmeliği, 1969: 7-8).

Anlaşılacağ1 üzere 1955 yılında çıkarılan yönetmelikle beraber eğitim enstitülerine akademik bir hüviyet kazandırılmak istenmiştir. Enstitüye asistan alınması, tez yazımı bunun göstergeleridir. Bununla, enstitü kadrolarının, yine kendi içlerinden yetiştirilmesi amaçlanmıştır. $\mathrm{Bu}$ durum eğitim enstitüsü öğretmenlerinin niteliği için olumlu bir yaklaşımdır. Elbette, başlangıçta asistanları yetiştirecek öğretmenlerin akademik niteliği ve üstünlüğü dikkate alınamamıştır. Zira tez hazırlattıracak ve hazırlanan tezin savunmasını alacakların tez hazırlamış ve savunmuş olması beklenir.

Eğitim enstitülerinin 1961-1978 yılları arasındaki öğretim kadroları incelendiğinde, Gazi Eğitim Enstitüsü hariç tutulursa, yalnızca İstanbul (Atatürk) Eğitim Enstitüsünün asistanlık kadrolarında çalışanların olduğu anlaşılmaktadır. İstanbul Eğitim Enstitüsünde 1963-1964 ders yılında 4 erkek 1 kadın, 1964-1965 ders yılında 3 erkek 1 kadın asistan istihdam edilmiştir (Milli Eğitim İstatistikleri Meslek-Teknik ve Yüksek Öğretim 1961/65, 1968: 538) . 1965-1966 ders yılında 3 erkek, 1966-1967 ders yılında 2 erkek 1 kadın asistan bulunmaktadır (Milli Eğitim İstatistikleri Yüksek Öğretim 1965-67, 1969: 50). 1967-1969 arasında iki ders yılında 2 erkek 1 kadın asistan görev yapmıştır (Milli Eğitim İstatistikleri Yüksek Öğretim 1967-70, 
1972: 120). 1971-1974 y1lları arasinda 8 erkek asistan, 1971-1972 ders y1lında 2, 1972-1973 ve 1973-1974 ders y1llarında ise 1 kadın asistan çalışmıştır (Milli Eğitim İstatistikleri Yüksek Öğretim 1970-1974, 1977: 96). 1974-1975 ders yılında 3, 1975-1976 ders yılında 1 erkek asistan görev yapmıştır. 1976-1977 ders yılında Enstitü bünyesinde asistan bulunmamakla birlikte bir ders yılı sonrasında okul kadrosunda 1 erkek asistan görev yapmıştır (Milli Eğitim İstatistikleri Yükseköğretim 1974-1978, 1980: 95). Yukarıda ifade edilen yıllar arasında Gazi ve İstanbul (Atatürk) Eğitim Enstitüleri dışındaki diğer eğitim enstitülerinde asistan kadrolarına yer verilmemiştir. Bu bilgilerden çıkan sonuç, 1955 ve sonraki yıllarda çıkarılan eğitim enstitüsü yönetmeliklerinde, asistanlık kadrosunun tanımlandığı, ancak yaygın olarak kullanılmadığıdır.

\subsection{Enstitü Memurları}

1947 ve ondan sonra çıkarılan eğitim enstitüsü yönetmeliklerinde enstitülerdeki memuriyetle alakalı işler ayrı ayrı belirlenmiş ve tanımlanan işleri yürütecek memurların görev ve sorumlulukları ele alınmıştır. Belirlenmiş görev ve sorumluluklarını yerine getirmeyen memurlarla ilgili yapılması gerekenler de yönetmeliklerde yerini almıştır. Memurların yürütecekleri işler, iç hizmetler, kâtip ve hesap işleri, ambar ve depo işleri, kitaplık işleri, evrak ve depo işleri olarak sıralanmıştır (Eğitim Enstitüsü Geçici Yönetmeliği, 1947; Eğitim Enstitüsü Yönetmeliği, 1955). Bunların dışında, yalnızca 1947 geçici yönetmeliğinde tanımlanmış, okuldaki ders araç-gereçlerinin saklanmasından, kullanılmasından ve ilgili defterin tutulmasından sorumlu bir ders araçları memurunun bulunduğu anlaşılmaktadır (Eğitim Enstitüsü Geçici Yönetmeliği, 1947: 175-176).

1953-1954 ders y1lında Necati Bey Eğitim Enstitüsü kadrosu incelendiğinde 6 memurun görev yaptığı anlaşılmaktadır. Memurların görevleri, iç hizmetler şefi, kâtip ve hesap memuru, kitaplik ve ders aletleri memuru, ambar ve depo memuru, laborant ve daktilo olarak tanımlanmıştır (Necati Öğretmen Okulu 1953-1954: 12). Yönetmeliklerde, memuriyetler arasında tanımlanmamış olmakla birlikte, Necati Bey Eğitim Enstitüsünde bir laborant unvanıyla bir memurun görev yaptığı anlaşılmaktadır. 1965-1966 ders yılında Bursa Eğitim Enstitüsünde de 6 memur görev yapmıştır. Ayrıca Enstitünün bir doktoru da bulunmaktadır (Demirel ve Becerikli, 2017: 358) .Diğer taraftan Bursa Eğitim Enstitüsünde 1968 y1lı itibariyle 12.946 eserin bulunduğu bir kütüphanenin ve kadrolu bir kütüphane memurunun olduğu anlaşılmaktadır (Demirel ve Becerikli, 2017: 351).

\subsection{Enstitü Doktoru}

Enstitülerde öğrenci ve personelin sağlık durumlarıyla ilgilenmek üzere bir doktor görevlendirilmiştir. Doktorun, enstitünün daimî bir personeli olmadığı, görevlendirme suretiyle çalıştığı anlaşılmaktadır. Zira 1955 yılında çıkarılan yönetmelikte doktorun, idarece belirlenen saatlerde enstitüye gelmesi planlanmıştır (Eğitim Enstitüsü Yönetmeliği, 1955: 15). Yönetmeliklerde dikkat çeken bir unsur, prevantoryum ve sanatoryuma gitmesi gereken öğrencilerin tespit edilmesinin enstitü doktorunun görevleri arasında özellikle zikredilmiş olmasıdır. İfade edilen görev her yönetmelikte belirtilmiştir. Prevantoryum, verem mikrobuna maruz kalmış olmakla birlikte henüz hastalığa yakalanmamış zayıf kişilerin vereme yakalanmasını önlemek amacıyla bakıldıkları sağlık kurumlarına verilen addır. Sanatoryum ise özellikle verem hastalarının tedavisi için kurulmuş sağlık kuruluşlarıdır.

1947 'de çıkarılan geçici yönetmelikte enstitü doktorunun her öğretim y1lı başında enstitüye yeni girecek öğrencileri muayene ederek sağlık yönüyle enstitüye devamlarını uygun görmediklerini belirlemesi hükmü bulunmaktadır (Eğitim Enstitüsü Geçici Yönetmeliği, 1947: 176). $\mathrm{Bu}$ hüküm öğretmenlik mesleğine sağlık yönüyle uygun olmayanların öğrencilik başlamadan belirlenmesi anlamına gelmektedir. Ancak daha sonra çıarılan yönetmeliklerde böyle bir tanımla yapılmamış, yalnızca dönem başında ve tatil öncesinde öğrencilerin muayene edilmesi öngörülmüştür (Eğitim Enstitüsü Yönetmeliği, 1955: 15; Eğitim Enstitüsü Yönetmeliği, 1968; Eğitim Enstitüsü Yönetmeliği, 1969) 


\subsection{Enstitü Bölüm Șefleri, Bölüm Temsilcileri}

1955 ve sonrasında "Bölüm Şefleri, Bölüm Temsilcileri” şeklinde tanımlanan görevler, 1932'de "Şube Meclisleri" (Altunya, 2006: 114), 1947'de "Şube ve Grup Başları" olarak belirtilmişlerdir. 1947 'de eğitim enstitüleri, toplu dersler bölümü ve tek dersler bölümü olarak planlanmıştır. Tek dersler bölümü müzik, resim-iş, beden eğitimi ve yabancı dil şubelerinden oluşacaktır. Toplu dersler bölümü ise yukarıda ifade edilen derslerin dışında tüm dersleri okutmaya yetkili öğretmenleri yetiştirecek bölümdür. Şube ve grup başları bu planın bir ürünüdür (Eğitim Enstitüsü Geçici Yönetmeliği, 1947: 173). Toplu dersler öğretmenliği anlayışından kısa süre içerisinde vazgeçilmesi nedeniyle 1955 'te çıkarılan yönetmelikte, her bir bölümün idaresi için bölüm şefleri tanımlanmıştır.

Bölüm şefleri, ilgili bölüm öğretmenler kurulunca iki yılda bir seçilir ve enstitü müdürünün teklifi üzerine Maarif Vekâletince atanırlar. Süresi biten bölüm şefleri yeniden seçilebilirler. Yeniden seçilemeyen bölüm şefinin bu görevi enstitü müdürünün teklifiyle Maarif Vekâletince alınır ve yerine yeni seçilen öğretmen tayin edilir. Bakanlıkça sözleşmeyle çalıştırılan uzmanlardan, sözleşmesinde bölüm şefliği yapacağına dair hüküm bulunanlar seçim şartına tabi tutulmazlar.

Kadrosuzluğu dolayısıyla veya başka sebeplerle şef tayin edilmeyen bölümlerde bu görevi bölüm öğretmenler kurulunca her öğretim yılı başında seçilecek bölüm temsilcisi öğretmen yapar.

Bölüm şeflerinin temel görevi, bölümde eğitim öğretim faaliyetlerinin yönetmeliklere ve programlara uygun bir şekilde yürütülmesini sağlamaktır. Bölüme ait işlerin konuşulup karara bağlanması için bölüm öğretmenler kurulunu en az ayda bir defa toplanmak ve toplantılara başkanlık etmek, kurulda alınan kararların uygulanmasını sağlamak da bölüm şeflerinin görevi arasındadır (Eğitim Enstitüsü Yönetmeliği, 1955: 20).

\subsection{Enstitü Kurulları}

Yönetmelikler arasında farklılıklar olmakla birlikte eğitim enstitüleri için temelde dört kurul belirlenmiştir. Bunlar öğretmenler kurulu, bölüm öğretmenler kurulu, enstitü kurulu ve disiplin kurullarıdır. Bölüm öğretmenler kurulu 1947 yılında çıkarılan geçici yönetmelikte, Disiplin Kurulu ise 1968 ve 1969 yıllarında çıkarılan yönetmeliklerde yer almamaktadır.

\subsection{1. Öğretmenler Kurulu}

Öğretmenler Kurulu enstitüdeki tüm öğretmenlerden oluşmaktadır. 1947 yılında yürürlüğe giren geçici yönetmelikte, kurulun, ihtiyaç duyulduğunda müdürün başkanlığında toplanması planlanmıştır. Kurulun görevi, enstitünün genel eğitim ve öğretim meseleleri ile müdürlük ve öğretmenler kurulu tarafından tespit edilen eğitim ve öğretim konularının müzakere edilmesi, şeklinde belirlenmiştir (Eğitim Enstitüsü Geçici Yönetmeliği, 1947: 175).

1955 yılında ve sonrasında çıkarılan yönetmeliklerde Öğretmenler Kurulunun görevleri genişletilmiş ve daha ayrıntılı tanımlanmıştır. 1955 yönetmeliğinde eğitim enstitüleri için asistan kadrosu tanımlandığından, Öğretmenler Kurulu da güncellenmiş ve kurula öğretmenlerin yanında asistanlar da eklenmiştir. Ayrıca kurulun yılda en az üç defa (dönem başlarında ve ders kesimlerinde) toplanması esası getirilmiştir. Kurulun görevleri ise aşağıdaki şekliyle tanımlanmıştır.

a) Enstitünün, yönetim ve eğitim-öğretim alanlarındaki genel gidişatını gözden geçirir.

b) Gelecek için ifade edilen temennileri tetkik ve tespit eder.

c) Yönetmelik hükümlerine göre gerekli seçimleri yapar.

d) Vekâletçe veya enstitü müdürlüğünce belirlenen konuları inceleyip karara bağlar.

Öğretmenler kurulu toplantılarına müdür başkanlık yapar. Kararlar, toplantıda bulunanların çoğunluğu ile alınır. Öğretmenler kurulu görüşmelerine ait zabıtların tutulması ve 
kararların yazılması işlerini kurulca seçilecek iki öğretmenle müdür başyardımcısı birlikte yaparlar. Kurul kararlarını bu iki öğretmenle birlikte müdür ve başyardımcısı imzalarlar. Kararlar ve zabıtları müdür başyardımcısı muhafaza eder (Eğitim Enstitüsü Yönetmeliği, 1955: 20-21).

\subsubsection{Bölüm Öğretmenler Kurulu}

Bölüm Öğretmenler Kurulu ilk defa 1955 yılında çıkarılan Eğitim Enstitüsü Yönetmeliği'nde yer almıştır. 1955 yılı sonrasında çıkarılan yönetmeliklerle benzer hükümleri içerir.

Bölüm Öğretmenler Kurulu, ilgili bölümün öğretmen ve asistanlarından oluşur. $\mathrm{Bu}$ kurul, bölüm şefi veya temsilcisinin başkanlığında en az ayda bir defa toplanır.

Bölüm öğretmenler kurulunun görevleri şunlardır:

a) Bölüm şefini veya temsilcisini seçmek,

b) Bölümün eğitim ve öğretim çalışmalarını inceleyip gereken karar ve tedbirleri almak,

c) İlgili öğretmenler tarafından hazırlanan müfredat programı tasarılarını gözden geçirerek birleştirmek ve bölüm ders dağıtma cetveli tasarısı hazırlamak,

d) Enstitü kurulunun tetkikine sunulacak eğitim-öğretim meselelerini tespit etmek,

e) İnceleme, kurs veya uygulama için başka yerlere gönderilmesi gereken sınıfların çalışma programlarını hazırlamak ve bu çalışmaları idare edecek öğretmenleri seçmek,

f) Mayıs ayı içinde bölüm öğrencilerinin umumi durumlarını gözden geçirerek her birinin durum fişine yazılacak hükmü tespit etmek ve yönetmeliğin 74 . maddesine göre enstitüden çıkarılması gerekenleri kararlaştırmak ${ }^{4}$

g) Yönetmelikle belirlenen veya idareye verilen diğer işleri yapmak.

Kurulun kararlarını, bölüm şefi veya temsilcisi yazarak toplantıda bulunan öğretmenlere imzalatıp muhafaza eder ve uygulamasını takip eder. Bölüm öğretmenler kurulunun program ve yönetmeliklerde değişiklik yapılmasına dair olan kararlarıyla bütçeden masraf yapılmasını gerektiren kararları, incelenmek üzere enstitü kuruluna gönderilir. Diğer kararlardan Maarif Vekâletince tasdik olunması gerekmeyenler, enstitü müdürlüğünün tasdikinden sonra uygulanır (Eğitim Enstitüsü Yönetmeliği, 1955: 21,22).

\subsubsection{Enstitü Kurulu}

1932 y1lında kabul edilen Gazi Terbiye Enstitüsü Talimatnamesi'ne göre, Enstitü için enstitü meclisi tanımlanmıştır (Altunya, 2006: 114). Eğitim Enstitüsü Geçici Yönetmeliği’nde (1947), enstitü kurulu olarak tanımlanan kurul, müdür başkanlığında, müdür başyardımcısı ile şube ve grup başlarından oluşmaktadır. Adı geçen yönetmeliğe göre: Enstitü kurulu, ders yılı içinde en az dört defa toplanır. Ders zümreleri ve şubeler arasında ortak eğitim-öğretim meselelerini inceleyip ahenkleştirmek, özellikle öğretimin, eğitim enstitüleri amaçlarına uygun olarak yürütülmesini sağlamak bu kurulun başlıca görevleridir (Eğitim Enstitüsü Geçici Yönetmeliği, 1947: 175).

1955 ve sonraki yıllarda çıkarılan yönetmeliklerde enstitü kurulu ve görevleri daha ayrıntılı tanımlanmıştır. Temel olarak kurul üyeleri yukarıda ifade edildiği gibidir. Ancak, eğer enstitünün hesap işleri ile idareye ve tahakkuk memurluğu görevine başyardımcıdan başka bir müdür yardımcısı tayin edilmişse o yardımcı da enstitü kuruluna üye olarak katılır. Ayrıca kurulun üye sayısı (müdür dâhil), 7'den az olursa enstitü öğretmenler kurulunun seçeceği öğretmenlerle 7'ye tamamlanır. Enstitü kurulunun görevleri aşağıdaki gibidir:

a) Eğitim ve öğretimin yönetmeliklerde tespit edilen amaçlara uygun olarak yürütülmesini sağlar.

\footnotetext{
${ }^{4}$ 74. madde, genel durumu itibariyle, mezun olduktan sonra tayini gereken görevi yapacak vasıfta bulunmayan öğrencilerin bölüm öğretmenler kurulu kararıyla enstitüden çıkarılması ve ilgiliye öğrenim belgesi verilmesini içerir. Çıkarma kararı, Maarif Vekâletinin tasdikinden sonra uygulanır.
} 
b) Bölümler arası eğitim, öğretim, yönetim ve uygulama çalışmalarını düzenler.

c) Enstitünün bütçe tasarısını hazırlar ve her yıl Maarif Vekâletince, enstitü umumi masraflarına karşılık verilen tahsisatın hangi ihtiyaçlara, ne miktarda ayrılacağını kararlaştırır.

d) Enstitü öğretmen kurulunun gündemini hazırlar.

e) Yönetmelikle veya idarece verilen diğer işleri yapar.

Enstitü kurulunun kararlarını müdür başyardımcısı yazar ve ilgililere imzalatarak muhafaza eder (Eğitim Enstitüsü Yönetmeliği, 1955: 22).

\subsubsection{Disiplin Kurulu}

1947 yılında çıkarılan Eğitim Enstitüsü Geçici Yönetmeliği’ne göre, disiplin kurulu, müdür başyardımcısı ile öğretmenler kurulu tarafından her öğretim yılı başında seçilen iki öğretmenden oluşur.

Enstitü disiplinini ilgilendiren hususlar hakkında karar alınması, yönetmelik hükümlerine ve emirlerine aykırı hareket eden öğrencilerin, ihtar ve tekdir dışında kalan cezalarla, cezalandırılması disiplin kuruluna ait bir iştir. Disiplin kurulu, kendisine görev olarak verilen işlere müdürün havalesiyle bakar. Toplantıya getirilecek hallerin dışında, kurul, enstitünün genel düzen ve disiplini ile ilgili meseleler için dönem başlarında olmak üzere yılda iki defa toplanır. Bu takdirde kurula enstitü müdürü başkanlık eder.

Eğitim enstitüsü öğrencilerinin, öğrenim hayatları boyunca göz önünde bulundurmaya mecbur olduğu esaslar şunlardır:

a) Bir yükseköğrenim kurumunun hayatına ve mensuplarına yakışmayacak her türlü kötü ve ayıp sayılan hareketlerden sakınmak ve yüksekokul öğrenciliği şerefini korumak,

b) Derslere, seminer ve uygulama çalışmalarına muntazam devam ederek öğretim ve yönetim heyetleri tarafından kendilerine verilecek ödevleri yerine getirmek, dikkat ciddiyet ve çalışkanlıktan ayrılmamak,

c) Arkadaşlarına ve çevredekilere daima sevgi ve saygı telkin edecek davranışlar sergilemek,

d) Enstitü yönetimince tespit olunacak iç talimata aykırı hareket etmemek (Eğitim Enstitüsü Geçici Yönetmeliği, 1947: 176).

1947'den farklı olarak, 1955 yılında çıkarılan yönetmelikle enstitü disiplin kurulunun, öğretmenler kurulunca her öğretim y1lı başında seçilecek üç öğretmen ve müdür başyardımcısından oluşması kararlaştırılmıştır. Ayrıca disiplin kurulunda durumu incelenen öğrencinin mensup olduğu bölüm şefi veya temsilcisi de kurulda hazır bulunur ve asıl üyeler gibi oy kullanır (Eğitim Enstitüsü Yönetmeliği, 1955: 22-23).

1968 ve 1969 yıllarında çıkarılan yönetmeliklerde disiplin kurulu tanımlanmamıştır. Her iki yönetmelikte müdür başyardımcının enstitü disiplin kuruluna başkanlık yapacağ 1 belirtilmektedir. Yine öğrencilerle ilgili maddelerde de disiplin kuruluna atıflar vardır. Ancak disiplin işlerinin nasıl yürütüleceğine, ilgili iki yönetmelikte de yer verilmemiştir (Eğitim Enstitüsü Yönetmeliği, 1968; Eğitim Enstitüsü Yönetmeliği, 1969). Bu durum 1968'de öğretmen yetiştiren yükseköğretim kurumları için ortak bir disiplin yönetmeliği çıkarılmış olmasından kaynaklanmaktadır. Zikredilen tarihten sonra eğitim enstitülerinin disiplin işleri, Öğretmen Yetiştiren Yüksek Dereceli Okullar Disiplin Yönetmeliği'ne göre yürütülmüştür (Becerikli, 2019: 123).

\section{Sonuç}

Osmanlı Devleti'nden alınan mirasın üzerine Cumhuriyet Dönemi'nde öğretmen yetiştiren yeni kurumlar da açılmıştır. Bu kurumların ilki, ortaokullara öğretmen yetiştirmek üzere açılmış olan Gazi Eğitim Enstitüsüdür. 1944'te ikincisi açılan eğitim enstitülerinin çoğaltılması kararının alınmasından sonra, onların yönetimini tasarlayan yönetmelikler 
1947 'den itibaren çıkarılmaya başlanmıştır. Yönetmelikler incelendiğinde yönetim için müdür ve yardımcıların dışında çeşitli kurulların oluşturulduğu anlaşılmaktadır.

İfade edilen ilgili kurullara gerek akademik anlamda ve gerekse idari anlamda önemli sorumluluk ve görevler yüklenmiştir. Bölüm şefleri ve temsilcilerinin seçimi, öğretim programlarından uygulamaya eğitim-öğretim işlerinin planlanması, tartışılması ve çözüm önerilerinin getirilmesi, öğretmen olamayacak öğrencilerin tespiti ve okuldan çıkarılmaları teklifi gibi görevler bunun göstergeleridir. Aynı şekilde enstitülerin tüm öğretmen ve asistanlarından oluşan Enstitü Öğretmenler Kuruluna, enstitünün eğitim-öğretim ve yönetim alanlarındaki genel gidişatını gözden geçirme sorumluluğu yüklenmiştir. Müdür başkanlığında oluşturulmuş olan Enstitü Kurulu, yine idari ve eğitim-öğretim konularıyla ilgilenen diğer bir üst kurul olarak tasarlanmıştır.

Gerek bölüm şefleri ve kurullarıyla gerek asistanlık kadrolarıyla eğitim enstitülerinin akademik bir yapıda kurulmasının planlandığı anlaşılmaktadır. İfade edilen kurullar ve öğretmenlerin, asistanlık yoluyla, kendi içerisinden yetiştirilmesi planı fakülte yönetimiyle benzerlik oluşturmaktadır. Ancak asistanlık kadrolarının eğitim enstitülerinde yaygın olarak oluşturulamaması bu konuda başarıya ulaşılamadığının bir göstergesidir. Bu beklentideki temel problem yeni öğretim kadrolarını oluşturacakların akademik bir hüviyetlerinin olmayışıdır. Fakat buna rağmen eğitim enstitülerinin müdür ve öğretmenlerinin planlanan akademik hüviyetten etkilendikleri aşikârdır. Müdür ve öğretmenlerin eğitim-öğretim konularıyla alakalı yazı ve kitaplar kaleme almış olmaları bunun bir göstergesidir.

Müdürlerinin vasıfları ve görev sürelerindeki istikrar enstitülerin kurumsallaşmasında ve başarısında önemli bir etken olmuştur. Diğer taraftan enstitü öğretmenleri niteliğinin de bu başarıda önemli bir faktör olduğu anlaşılmaktadır. Enstitü öğretmenleri, eğitim almaları amacıyla yurtdışına gönderildikleri gibi yurt içerisinde çeşitli kurslara da tabi tutulmuşlardır.

\section{Kaynaklar}

Alkım, (1974-1976). Say1lar: 53-64.

Altunya, N. (2006). Gazi Ĕgitim Enstitüsü, Gazi Orta Öğretmen Okulu ve Ĕgitim Enstitüsü (1926-1980), Ankara: G:Ü: İletişim Fakültesi Basımevi.

Akyüz, Y. (2012). Türk Eğitim Tarihi, Ankara: Pegem Akademi.

Ayas, N. (1948). Türkiye Cumhuriyeti Milli Eğitimi Kuruluşlar ve Tarihçeler, Ankara: Milli Eğitim Basımevi.

Becerikli, S. (2019). Öğretmen Yetiştirmede İstanbul Yüksek Öğretmen Okulu Modeli (19241978), Bursa Uludağ Üniversitesi, Eğitim Bilimleri Enstitüsü, Doktora Tezi, Bursa.

Becerikli, S. ve Demirel M. (2017). Osmanlı'dan Cumhuriyet Bursa'sına Miras Kalan Öğretmen Okulları (1883-1975), History Studies, 9(1): 65-84.

Beyzadeoğlu, Y.Z. (1976). Mektupla Öğretimin Sonu, Alkım, 9(63-64): 16-18.

Demirel, F. (2012). Osmanlı Eğitim Sisteminin Modernleşmesi Sürecinde Hiyerarşi, Uludăg Üniversitesi Ĕ̈itim Fakültesi Dergisi, 25(2): 507 - 530.

Demirel, M. (2002). Türk Eğitiminin Modernleşmesinde Rüşdiye Mektepleri, Türkler, XV: 4460.

Demirel, M. ve Becerikli, S. (2017). Bursa Eğitim Enstitüsü, Uludağ Üniversitesi Ĕgitim Fakültesi Dergisi, 30(1): 341-374.

Devlet Arşivleri Başkanlığı, Cumhuriyet Arşivi: 180.09.0.0/78.382.1.

Duman, T. (1991). Türkiye'de Ortaöğretime Öğretmen Yetiştirme (Tarihi Gelişimi), İstanbul: Milli Eğitim Basımevi. 
Eğitim Enstitüleri Geçici Yönetmeliği. (03.03.1947) Tebliğler Dergisi, 9(423): 173-180.

Eğitim Enstitüsü Yönetmeliği. (1955). İstanbul: Matbaacılık Okulu.

Eğitim Enstitüsü Yönetmeliği. (25.11.1968). Tebliğler Dergisi, 31(1530): 495-502.

Eğitim Enstitüsü Yönetmeliği. (16.06.1969). Resmi Gazete, (13224): 1-11.

Erdem, A. (2015). Türkiye'deki Öğretmen Yetiştirmenin Amaçları, Belirsizlikleri, Çelişkileri, Öğretmen Ĕgitimi ve Ĕgitimcileri Dergisi, C.(1): 16 - 38 .

Güçlü, M. (2013). 1950 ve 1980 Yılları Arasında Türkiye'de Öğretmen Yetiştirme Alanında Görülen Temel Eğilimler, OPUS-Türkiye Sosyal Politika ve Çalışma Hayatı Araştırmaları Dergisi, 3(4): 83-91.

Kavcar, C. (2002). Cumhuriyet Döneminde Dal Öğretmeni Yetiştirme, Ankara Üniversitesi Eğitim Bilimleri Fakültesi Dergisi, 35(1): 1-14.

Maarif-i Umumiye Nizamnamesi. (1286). İstanbul.

Maarif Vekâleti 1339-1340 Ders Senesi İhsaiyat Mecmuası. (1341). İstanbul.

Milli Ĕ̈itim İstatistikleri Meslek-Teknik ve Yüksek Öğretim 1961/65. (1968). Ankara: Devlet İstatistik Enstitüsü Matbaas1.

Milli Eğitim İstatistikleri Yüksek Öğretim 1965-67. (1969). Ankara: Devlet İstatistik Enstitüsü Matbaas1.

Milli Ĕ̈itim İstatistikleri Yüksek Öğretim 1967-70. (1972). Ankara: Devlet İstatistik Enstitüsü Matbaas1.

Milli Ĕ̆gitim İstatistikleri Yüksek Öğretim 1970-1974. (1977). Ankara: Devlet İstatistik Enstitüsü Matbaas1.

Milli Eğitim İstatistikleri Yüksekögrretim 1974-1978. (1980). Ankara: Devlet İstatistik Enstitüsü Matbaas1.

Necati Ĕgitim Enstitüsü (1948). Balıkesir.

Necati Öğretmen Okulu 1953-1954, Balıkesir.

Orta Muallim Mektebi Muvakkat Talimatnamesi. (21.12.1927). Tebliğler Dergisi, 12: 1-84.

Öztürk, C. (1998). Türkiye'de Dünden Bugüne Öğretmen Yetiştiren Kurumlar, İstanbul: Marmara Üniversitesi Atatürk Eğitim Fakültesi Yayınları.

Şahin, M. (2002). İzmir Eğitim Enstitüsü, Tarih ve Toplum, 38(225): 34-41.

Şevket, S. (1924). Orta Darülmuallimat ve Darülmuallimin, Muallimler Mecmuası, 2(20): 575.

Taşer, S. (2010). Tanzimat'tan Cumhuriyet'e Modernleşme Sürecinde Öğretmen Yetiştiren Kurumlarda Eğitim Yönetimi ve Denetimi, Selçuk Üniversitesi, Sosyal Bilimler Enstitüsü, Doktora Tezi, Konya.

Ünal, U. ve Birbudak T. (2013). İstanbul Darulmuallimini (1948-1924), Ankara: Atatürk Araştırma Merkezi.

Yılman, M. (1987). Türkiye'de Ortaöğretime Öğretmen Yetiştirme Sisteminin Pedagojik Temelleri, Dokuz Eylül Üniversitesi Sosyal Bilimler Enstitüsü, Doktora Tezi, $\quad$ İzmir.

Zeran F. ve G. Jones. (1958). İdarecilerin Vazife ve Mesuliyetleri, (Çev: İbrahim Özgür), Öğretmence: 4-8. 